\title{
GENDER INFLUENCE ON THE PERCEPTION OF CELEBRITY ENDORSEMENT
}

\author{
Laura Lazăr \\ Bucharest University of Economic Studies, Romania \\ E-mail: laura_lazar10@yahoo.com
}

(Received: March 2020; Accepted: May 2020; Published: June 2020)

\begin{abstract}
Celebrity endorsement is a common instrument in marketing. Celebrities are also present in commercials, and this phenomenon is nowadays a trend. This kind of publicity has a high potential since customers are pulled into the VIPs. They are overpowered by their regular daily existence, so they need standards and good examples. This is the motivation for using superstar brand envoys in advertisings as an excellent promoting technique of brands and products. In the period of data and promotions, the tributes can get the consumers' consideration in publicizing and to expand how the promoted item is being perceived. This is because of their fame, glamour, elegance and charisma. For this reason, the marketers are looking for popular, famous, beautiful, positive testimonials to drive a company's image and its products. The celebrity brand ambassadors thus play a significant role in a brand's advertisement and reputation, but also in the consumers' lives. The stars' everyday lives, their conduct, the products they use, affect the attitude of the customers of life and the decision to purchase. The purpose of this paper is to determine if celebrity endorsement works for all the consumers or the perception of this trend is different according to the gender of the people. Two groups of customers were asked about celebrity endorsement whether their appearance in ads affects their decision and the desire to purchase a product or not. Recent results have shown that there are still differences between the two categories of customers, men and women, in the perception of celebrity endorsement. All of them think advertising is important, and sometimes they change their choices according to a product's advertisement. The difference is that women appear to believe more in the endorsements of celebrity brands and their impact effect on the product being marketed than men, who are more pragmatic and reticent about this trend.
\end{abstract}

Keywords: celebrity endorsement, advertising, gender, signal strategy, consumer, attention, buying decision, brand identity, human brands, social media, commitment.

JEL Codes: M10, M31

*Corresponding author: Laura Lazăr. E-mail: laura_lazar10@yahoo.com

Copyright $(C 2020$ The Author(s). Published by VGWU Press

This is an Open Access article distributed under the terms of the Creative Commons BY 4.0 license (Creative Commons - Attribution 4.0 International - CC BY 4.0) which permits unrestricted use, distribution, and reproduction in any medium, provided the original author and source are credited.

Sciendo Studia Universitatis "Vasile Goldis" Arad. Economics Series Vol 30 Special Issue 2/2020

ISSN: 1584-2339; (online) ISSN: 2285 - 3065 
Lazăr, L., (2020)

Gender influence on the perception of celebrity endorsement

\section{Introduction}

The use of celebrities in advertisements has become a phenomenon in the age of information and communication. The persons in charge of the marketing department understood the value of the involvement of the celebrities in promotions and the effect of the famous personalities on consumers ' buying decision. As a result, the number of commercials with celebrities is continuously increasing. The stars have a major effect on regular people's behavior and could get them to choose the products they endorse. Testimonial ads can be done through various platforms, such as television, print, electronic and social media (Zipporah \& Mberia, 2014). Individuals who watch publicity highlighting a celebrated individual tend to observe more the qualities of the superstar and to ramble about them. That is likewise on the grounds that normally individuals will in general watch longer the well-known faces in promotion than they do with new ones (Devue et al., 2009; Nistoreanu et al., 2019). Here shows up the dominating impact. The VIPs grab the eye of the customers, so they don't give any longer the required consideration to the promoted brand (Erfgen et al., 2015). Picking the tribute is likewise an important choice for advertisers. According to Byrne et al. (2003), choosing the right popular, credible, influential, charismatic, and internationally recognized individual is the secret to success in advertising. It should be of interest to the public and get customers closer to the brand being advertised. They would also be guided by celebrities to make the buying decision they like. It's obvious that some people have a favorable impression on Celebrity Brand Ambassadors and some people don't. Some of them prefer to include this advertisement category in the category of fake news. So they are not impacted by this type of advertising or their shopping decision (Tantau et al., 2018). More studies have proved that the behavior of people differs depending on the generation to which they belong (Popa \& Pelau, 2016). The question is if the impact of celebrity endorsement is the same according to the gender category of the consumers. The participants in this analysis are two categories of buyers - men and women. The purpose is to analyze how the reactions to the celebrity endorsement men compared with women are.

\section{Literature review}

In the society where consumers have several options, advertisement (Tremblay and Polasky, 2002) is one approach that businesses usually use to achieve the differentiation of the products. Celebrity endorsement is very popular among all advertising campaigns and is widely adopted for almost any form of product or service available (Erdogan et al., 2001; Mehulkumar, 2005; Doss, 2011)

A celebrity is a person of notoriety who receives public attention. For this reason,

14 Sciendo Studia Universitatis "Vasile Goldis" Arad. Economics Series Vol 30 Special Issue 2/2020 ISSN: 1584-2339; (online) ISSN: 2285 - 3065

Web: publicatii.uvvg.ro/index.php/studiaeconomia. Pages $13-23$ 
Lazăr, L., (2020)

Gender influence on the perception of celebrity endorsement

the use of popular advertisers in advertisements is very efficient, because they gain customers ' attention through their name and image. The popular people are like human brands, as they are branding and marketing experiments with their acts and appearances on stage, their behavior in private life, their online activities. The celebrity's daily life and its actions are private, but all are publicly observed. Some actions create brand identities so businesses sell various goods through celebrity endorsement (Holmes \& Redmond, 2014).

According to McCracken (1989) a famous person has a stronger effect on an individual's buying behavior than a normal person. Nevertheless, he also assumes that advertisements with celebrities are typical of modern marketing. The marketing personalities can pass on the items being marketed to their established identity. This thing is in favor of the customers.

Famous people are a wonder in promoting today. However, since the business happens, these exist. This sort of promotion has a high potential. The supposed tributes are amazing drivers of a company's notoriety. Consequently, those answerable for advertising are scanning for such gorgeous, well known, reliable and fruitful VIPs. Through these properties, the feelings join an item's utilization. Purchasers need the tributes now since they are disappointed by the vulnerability of regular day to day existence, so as an endurance methodology they need good examples and qualities. The big names in this manner assume a significant job for promoting as well as for the day by day lives of shoppers. The good examples, their conduct, and in this manner the items used by them, disentangle individuals' direction throughout everyday life and make it simpler to choose. This is the reason the tribute publicity works.

The stars are additionally a specialized device for organizations. They can possibly build showcase mindfulness and income, making advertisements compelling right now. Add to this the way that VIPs convey with them their own experience which brings about a closer and increasingly well-known connection among them and customers. All the time, clients consider being endorsers as their very own feature lives and that is the reason they don't hesitate to respond and communicate sentiments about them. In some cases, they're propelled by the open individual's demeanor, emotions or conduct (Bagozzi and Dholakia, 2002).

Nevertheless, marketers continue to look for ways to measure and increase the efficacy of their commercials through studying the impact of celebrity endorsements on consumer behavior. Another idea for advertisers is to include celebrities in the banner image because this typically triggers immediate customer interest.

By connecting a brand with a celebrity, a brand can take advantage of a celebrity's unique and beneficial secondary brand associations and gain market recognition, transfer positive celebrity-related associations onto the brand, build brand loyalty 
Lazăr, L., (2020)

Gender influence on the perception of celebrity endorsement

and ultimately increase the value of the endorsed brand (Keller, 2008).

The fans are interconnected consumers who actively respond to the brand and build brand value (Schau et al., 2009).

In the contemporary commercial center, big names are a typical element, some of the time turning into the face, or logo, of shopper items and brands, however of associations themselves. For instance, in Australia, Hugh Jackman is the essence of Lipton Iced Tea, Nicole Kidman shows up in Nintendo DS ads and George Clooney collaborates of Nespresso espresso with John Malkovich. Brands utilize acclaimed and affable big names by abusing the prominence of the big names (Keller, 2008).

Celebrity endorsements lead to higher recall rates for advertisements (O'Mahony and Meenaghan, 1997/1998) and improved contact with potential clients by building connections between clients and the advertised brand (Atkin and Block, 1983).

Celebrities are human brands - they are on - and off-stage, off - and on-line, public or private shows are marketing and branding experiments. Their regular activities and principles are private but are played out in public.

Additionally, famous people help break down cultural barriers (Mooij, 2004), help reposition brand and company images (Till and Shimp, 1998), and ultimately increase endorsed product profits (Kaikati, 1987). It has been found that the announcement of a celebrity endorser contract has a positive impact on stock returns, making celebrated investments worthwhile.

Those activities establish company and business profiles. The human brand identities, therefore, promote goods by granting inanimate brands personality qualities through endorsements and persuasions (Holmes \& Redmond, 2014).

Byrne et al. (2003) agree that the secret to success in an organized advertising campaign is to select a popular, trustworthy, and internationally known person. Such goods are not very different in terms of price or quality. Celebrity plays a significant role here: to get consumers closer to a specific brand and to give them the right motivation to make the buying decision they want.

A celebrity is marked as an effective endorsement using three requirements: appearance, popularity, and brand congruence (Erdogan 1999). A more appealing star spreads the message supported by the star more efficiently (Till \& Busler, 2000).

Just a few attributes like elegance, charm or an outstanding lifestyle, celebrities enjoy high exposure and are different from ordinary people. According to Friedman and Friedman (1979), a celebrity endorser is a person who is known through the public successes in areas other than that of the endorsed product class. These often seem to hit the popular people on a higher level of recognition, loyalty,

16 S sciendo Studia Universitatis "Vasile Goldis" Arad. Economics Series Vol 30 Special Issue 2/2020 ISSN: 1584-2339; (online) ISSN: 2285 - 3065

Web: publicatii.uvvg.ro/index.php/studiaeconomia. Pages $13-23$ 
Lazăr, L., (2020)

Gender influence on the perception of celebrity endorsement

and respect compared to other endorsers. Nowadays, in an age of intense competition, where all brands aspire to stay in the buyers' minds and encourage them to purchase their products, celebrity endorsement is a golden opportunity. Success can feel like a catalyst. "Celebrities as Brands" represents a sales challenge. The current notion of success is far from ideal to handle. Today, this trend is regarded primarily as a business instrument that brings benefits to a company. The crucial thing is that celebrities and businesses suit together. The testimonials have to fit promoted products. The role of celebrities in the message of an advertisement should be specific, rather than random.

Celebrity endorsement is a method of cash-burning. That is because customers pay great attention to their position in society. They also want to wear the right clothing, drink the right cocktail, buy the right fragrance. The stars are like a reference category, for a lot of customers. They are searching for details, they're being attracted by celebrities, they're spending time and energy to look and be like them. It happens because celebrities are icons, beloved characters for ordinary people, because of their lifestyle and social media presence. It is about the social impact hypothesis. So a normal person attempts to copy a public person to look like her in an identification process. People have the activities of a comparative big name and purchase marks that they advance for framing their own personality.

Brands are putting intensely in getting big name supports. First off, until 2020 Adidas marked an agreement with Cristiano Ronaldo for $£ 14.2 \mathrm{M}$ every year. LeBron James is the NBA's present lord of sponsorship, with an expected $\$ 48$ million off-court income. Given this fascination with superstar underwriting brands, be that as it may, the relationship with a VIP doesn't really support the brands (Zhou and Whitla, 2013), and an away from of the procedures supporting support impacts stays a significant objective for chiefs and analysts (Bergkvist and Zhou, 2016).

Superstar notoriety at that point influences different markers of support adequacy, including brand, item, and ad mentalities, just as buying aims (Friedman and Friedman, 1979; Pornpitakpan, 2003; Silvera and Austad, 2004).

It has been found that any famous person is more persuasive than every other endorser. The popularity of the stars gives them a stronger persuasive ability. If a well-known individual is marketing the products, consumers appear to make a more favorable decision. But a balance has to be established between celebrity and product, a harmony between these, not artificial and forced, but true.

Celebrity recognition now acts as a networking device. A well-chosen celebrity will draw consumers, and their attention, to a product or brand. For example, the singer Fergie has shown the customer how many kilograms she's lost, possibly with Weight Watchers' support (Kotler \& Keller, 2008). In this case, the celebrity has a capital interest in choosing a figure from advertising. The public figure chosen for 
Lazăr, L., (2020)

Gender influence on the perception of celebrity endorsement

the business should be known and made known to the public. So this will ideally meet the advertised products or services.

Celebrity endorsement research focuses primarily on celebrity - brand congruence, which is seen as the primary requirement for such marketing communication to be successful. Throughout this view, the customer behaves as an outsider to the interaction between celebrity and brand, while the efficacy of endorsement depends on consumer-psychological factors such as his personality or social influences.

Superstar support and internet-based life promotions fill in as a showcasing commitment structure to investigate how different on-screen characters publicists, the press, ability the executives, communicate systems, purchasers and VIPs themselves-meet up to co-make singular brand personalities in a get together of activity. Such communications, as a result, offer support back to the assets of those partners themselves. The rise of web-based life speaks to a rich wellspring of social reality. Such co-creation stages fill in as desultory and serious components to create, re-make, persuade, and arrange characters for social and monetary purposes for VIP partners.

Not only sell stuff and brands but celebrities also have a strong impact on influencing consumer perceptions and preferences on all aspects of popular culture and public life.

The number of stars in the commercials has risen in the last years. The marketers accepted that the purchasing decisions of the people are impacted by Celebrity Brand Ambassadors. A star will replace the lesser properties of one element. They have a strong impact on consumer behavior, and they motivate customers to buy specific products. Testimonial ads can be broadcast online, on TV, or by social media (Zipporah \& Mberia, 2014).

\section{Methodology and empirical data}

The research's goal is to evaluate the perception of consumers regarding celebrity endorsement, based on their gender. The 12 items related to celebrity brand ambassador include assumptions about their involvement in advertisements, whether or not the celebrities influence the actions of the customer, whether or not they influence their buying decision. The items were included in a multiple topic survey conducted on a sample of 252 respondents in the period December 2018January 2019 in the urban population. The validity of the sample is granted by the Cronbach Alpha value, which is related to the perception of consumers on celebrity endorsement. The Cronbach Alpha value of 0.847 suggests a significant data validity in this case. Within this research, we rely on the behavioral and perceptional differences based on the respondents' gender. The study was divided into two gender-based groups: group 1 (defined as G1) consisted of women, and

18 Sciendo Studia Universitatis "Vasile Goldis" Arad. Economics Series Vol 30 Special Issue 2/2020 ISSN: 1584-2339; (online) ISSN: 2285 - 3065

Web: publicatii.uvvg.ro/index.php/studiaeconomia. Pages $13-23$ 
Lazăr, L., (2020)

Gender influence on the perception of celebrity endorsement

group 2 (defined as G2) included men. The survey contains 252 valid responses, of which 132 are women (G1) and 120 are men (G2). The results will be presented below.

\section{Results and discussions}

Survey results show that there are items showing variations for the two gender groups and there are also items showing that the opinion of the customers about celebrity endorsement is very similar, regardless of the respondents' gender. From the 12 items analyzed, 7 indicate significant differences and the remaining 5 give similar outcomes. Table 1 displays the results for these items. The perception which shows the highest difference is the idea that the products promoted or worn by testimonials, provide the consumers with a better image. Women tend to agree more with the affirmation that the products which are promoted by testimonials provide them appearance $(\mathrm{MG} 1=3.2424)$, while men are more realistic and tend to disagree with it $(\mathrm{MG} 2=2.8833)$. This comes out also from the item which says that the celebrity endorsers guarantee for the quality of the products they promote. In this case, the results were as follow indicating again that women think that the celebrities guarantee the quality of the promoted products from the commercials, more than men $(M G 1=2.6667)$. They don't agree that much with it $(M G 2=2.3917)$. This shows that male respondents are more open to information and they don't trust commercials with celebrities that much. Another difference in the perception between the two groups of consumers would be also regarded as the higher quality of products promoted by a famous person. Consumers from the first group, also female respondents, think that the products from commercials with a celebrity have a higher quality than products from commercials with normal people, without testimonials (MG1=2.6667). Men are again more reticent to this affirmation (MG2=2.4000). The next affirmation which brings differences between perceptions according to the gender of the consumers would be the affirmation that they pay more attention to the commercials which include celebrities. Again women tend to agree more with it $(\mathrm{MG1}=3.0303)$, then the male respondents $(\mathrm{MG} 2=2.7083)$. In the same category, we can include the item which says consumers often buy products that are worn or promoted by celebrities. Here are women tending to confirm this $(\mathrm{MG} 1=2.5606)$, in opposite to men $(\mathrm{MG} 2=2.2417)$. The affirmation, which says that celebrities bring benefits to the products they advertise, shows also a little difference in perception between the two categories of gender. Women don't agree that much with this idea $(\mathrm{MG} 1=3.7652)$, as male respondents do $(\mathrm{MG} 2=4.0750)$. The last item which shows differences between the mentalities of two types of gender is buying a product promoted by a famous person only if they like him/her. Female respondents tend to agree more with the idea that they buy products promoted by celebrities only if they like the testimonial (MG1=2.4167), 
Lazăr, L., (2020)

Gender influence on the perception of celebrity endorsement

while the group of men doesn`t $(\mathrm{MG} 2=2.2417)$.

Table 1 Perception of men and women on celebrity endorsement

\begin{tabular}{|l|r|c|}
\hline \multicolumn{1}{|c|}{ Item } & $\begin{array}{c}\text { Mean } \\
\text { G1 } \\
\text { (Women) }\end{array}$ & $\begin{array}{c}\text { Mean } \\
\text { G2 } \\
\text { (Men) }\end{array}$ \\
\hline I often buy products that are worn or promoted by celebrities & 2.5606 & 2.2417 \\
\hline I pay more attention to the commercials which include celebrities & 3.0303 & 2.7083 \\
\hline I think the products promoted by celebrities have a better quality & 2.6667 & 2.4000 \\
\hline $\begin{array}{l}\text { I think the products promoted by celebrities provide me a better } \\
\text { image }\end{array}$ & 3.2424 & 2.8833 \\
\hline Celebrities guarantee for the quality of the promoted products & 2.6667 & 2.3917 \\
\hline I think the products promoted by celebrities are luxury products & 2.7955 & 2.9333 \\
\hline $\begin{array}{l}\text { I think I have a better social status if I wear products promoted by } \\
\text { celebrities }\end{array}$ & 2.2955 & 2.1250 \\
\hline I buy a product promoted by a star only if I like him/her & 2.4167 & 2.2417 \\
\hline I believe celebrities bring benefits to the products they promote & 3.7652 & 4.0750 \\
\hline $\begin{array}{l}\text { Celebrities can also have a negative impact on the image of the } \\
\text { promoted products }\end{array}$ & 4.4545 & 4.4167 \\
\hline Consumers tend to idolatrize and copy certain public figure & 5.0379 & 5.1250 \\
\hline $\begin{array}{l}\text { A consumer often changes their preferences depending on the } \\
\text { advertising }\end{array}$ & 4.7273 & 4.7500 \\
\hline
\end{tabular}

Observation: G1 are women; G2 are men

Source: Own research results

There are also similar perceptions regarding celebrity endorsement, despite the gender of the buyers. We can observe this in affirmations like the one in which a consumer often changes their preferences depending on the advertising $(\mathrm{MG} 1=4.7273, \mathrm{MG}=4.7500)$. Both of the groups agree with this idea. Another item which both groups strongly agree with is that the consumers tend to idolatrize and copy certain public figures $(\mathrm{MG} 1=5.0379, \mathrm{MG} 2=5.1250)$. Another perception which both groups of respondents have is that a testimonial can also have a negative impact on the image of the promoted product $(\mathrm{MG} 1=4.4545$, MG2=4.4167). Also, both men and women don`t think that the products promoted by celebrities are luxury products $(\mathrm{MG} 1=2.7955, \mathrm{MG} 2=2.9333$ ). The last affirmation which shows similar perception between according to the gender of the respondents would be that the products promoted or worn by testimonials, provide them a better image in the society. This seems to be less important for men but for women as well. They both disagree with the fact that a product that is worn or advertised by a celebrity will provide them a better image in today's society $(\mathrm{MG} 1=2.2955, \mathrm{MG} 2=2.1250)$. 
Lazăr, L., (2020)

Gender influence on the perception of celebrity endorsement

\section{Conclusions}

Research findings indicate that there are differences and similarities in terms of customer perception of celebrity endorsement according to their gender. As for differences, it came out that women tend to believe more in testimonials from the commercials then men do.

Women think that a product which is promoted by a famous person will provide them a better image, they agree with the fact that celebrity endorsers guarantee for the quality of the products they promote, female respondents also agree that the products from commercials with a celebrity have a higher quality then products from commercials without testimonials, they pay more attention to the commercials which include celebrities and in the end, women often buy products that are worn or advertised by the famous person. On the other hand, men are more realistic. They tend to disagree with all this and don`t believe that a product which is promoted by a celebrity is necessarily a higher quality product, that it provides a better image, don't pay more attention to a commercial only because it contains a testimonial and don`t buy products only because they are advertised by a charismatic, well-known person.

Both men and women also think similarly in some situations. They both agree that they often change their preferences depending on the advertising they see and are aware that consumers tend to idolatrize and copy certain public figures. They all admit that a testimonial can also have a negative impact on the image of the promoted product and don't agree with the item that the products promoted by celebrities are necessarily luxury products. They all admit that the products promoted or worn by testimonials, won't provide them a better image in the society. This seems to be less important for men but for women as well. They both disagree with the affirmation that a product that is worn or promoted by a testimonial will provide them a better image in today`s society.

So, it seems that celebrity endorsement has a greater impact on women than on men. A reason, therefore, would be the fact that men are more realistic, more reticent, and don't pay much attention to the commercials at all. They have more time to search for information and do a lot of research about a desired product or service if they have that product on their wish list, so it doesn't need to be promoted by a celebrity brand ambassador.

\section{Acknowledgments}

The author thanks the anonymous reviewers and editor for their valuable contribution.

\section{Funding}

This work was co-financed from the European Social Fund through Operational Programme Human Capital 2014-2020, project number POCU/380/6/13/125015 
Lazăr, L., (2020)

Gender influence on the perception of celebrity endorsement

„Development of entrepreneurial skills for doctoral students and postdoctoral researchers in the field of economic sciences".

\section{Author Contributions}

The entire article was written by Laura Lazăr.

\section{Disclosure Statement}

The author has not any competing financial, professional, or personal interests from other parties.

\section{References}

1. Atkin, C., Block, M., (1983), Effectiveness of celebrity endorsers, Journal of Advertising Research 23 (1), 57-61

2. Bagozzi, R.P., Dholakia, U.M., (2002), Intentional social action in virtual communities, Journal of Interactive Marketing, 16(2), 2-21

3. Bergkvist, L., Zhou, K.Q., (2016), Celebrity endorsements: A literature review and research agenda, International Journal of Advertising, 35(4), 642-663

4. Byrne, A., Whitehead, M., Breen, S., (2003), The naked truth of celebrity endorsement, British Food Journal, 105(4/5), 288-296

5. Devue, C., Van der Stigchel, S., Brédart, S., Theeuwes, J., (2009), You do not find your own face faster; you just look at it longer, Cognition, 111, 114-122

6. Doss, S.K., (2011), The transference of brand attitude: the effect on the celebrity endorser, Journal of Management Marketing Research, 7, 1-11

7. Erdogan, B.Z., (1999), Celebrity endorsement: A literature review, Journal of Marketing Management, 15(4), 291-314

8. Erdogan, B.Z., Baker, M.J., Tagg, S., (2001), Selecting celebrity endorsers: the practitioner's perspective, Journal of Advertising Research, 41(3), 39-48

9. Erfgen, C., Zenker, S., Sattler, H., (2015), The vampire effect: When do celebrity endorsers harm brand recall?, International Journal of Research in Marketing, 32, $155-163$

10. Friedman, H.H., \& Friedman, L., (1979), Endorser effectiveness by product type, Journal of Advertising Research, 19(5), 63-71

11. Holmes, S., Redmond, S., (2014), Socialising celebrity, Celebrity Studies, 5(3), 223-224

12. Kaikati, J.G., (1987), Celebrity advertising: a review and synthesis, International Journal of Advertising, 6 (2), 93-105

13. Keller, K.L., (2008), Strategic Brand Management: Building, Measuring and Managing Brand Equity, Prentice Hall, New Jersey

14. Kotler P., Keller, K.L., (2008), Managementul Marketingului, Teora (5 ${ }^{\text {th }}$ Ed.)

22 Sciendo Studia Universitatis "Vasile Goldis" Arad. Economics Series Vol 30 Special Issue 2/2020 ISSN: 1584-2339; (online) ISSN: 2285 - 3065

Web: publicatii.uvvg.ro/index.php/studiaeconomia. Pages $13-23$ 
Lazăr, L., (2020)

Gender influence on the perception of celebrity endorsement

15. McCracken, G., (1989), Who is celebrity endorser? Cultural foundations of the celebrity endorsment process, Journal of Consumer Research, 16(3), 310-321

16. Mooij, M., (2004), Consumer Behavior and Culture, Consequences for Global Marketing and Advertising, Sage Publications, London

17. Nistoreanu, P., Pelau, C., Lazar, L., (2019), Product versus celebrity - An eyetracking experiment for the determination of the attention-catcher in advertising, Proceedings of the $13^{\text {th }}$ International Conference of Business Excellence, 10791086

18. O'Mahony, S., Meenaghan, T., (1997/1998), The impact of celebrity endorsements on consumers, Irish Marketing Review 10 (2), 15-24

19. Popa, A., Pelau, C., (2016), Differences in the clothing brand perception depending on generation, Industria Textila, 4, 260-264

20. Pornpitakpan, C., (2003), Validation of the celebrity endorsers' credibility scale: Evidence from Asians, Journal of Marketing Management, 19(1-2), 179-195 21. Schau, H.J., Muñiz, A.M., Arnould, E.J., (2009), How brand community practices create value, Journal of Marketing, 73(5), 30-51

22. Silvera, D.H., Austad, B., (2004), Factors predicting the effectiveness of celebrity endorsement advertisements, European Journal of Marketing, 38(11/12), $1509-1526$

23. Tanțău, A., Pelau, C., Pop, M., (2018), Fake news in the energy industry, Proceedings of the $4^{\text {th }}$ BASIQ International Conference on New Trends in Sustainable Business and Consumption (BASIQ), 204-210

24. Till, B.D., Busler, M., (2000), The match-up hypothesis: Physical attractiveness, expertise, and the role of fit on brand attitude, purchase intent and brand beliefs, Journal of Advertising, 29(3), 1-13

25. Till, B.D., Shimp, T.A., (1998), Endorsers in advertising: the case of negative celebrity information, Journal of Advertising, 27(1), 67-82

26. Tremblay, V.J., Polasky, S., (2002), Advertising with subjective horizontal and vertical product differentiation, Rev. Industrial Organ. 20(3), 253-265

27. Zhou, L., Whitla, P., (2013), How negative celebrity publicity influences consumer attitudes: The mediating role of moral reputation, Journal of Business Research, 66(8), 1013-1020

28. Zipporah, M.M., Mberia, H., (2014), The Effects of Celebrity Endorsement in Advertisements, International Journal of Academic Research in Economics and Management Sciences, 3(5), 178-188 